\title{
An Empirical Study on the Economic Effect of Financial Cooperation Among Countries of the "Silk Road Economic Belt"
}

\author{
Xiaosong Zheng, Lijun Jia
}

\author{
Shanghai University \\ No.20 Cheng Zhong Road, 201899 Shanghai, P.R.China \\ E-mail.xiaosong.zheng@shu.edu.cn, jialijun@t.shu.edu.cn \\ cross $^{\text {ref }}$ http://dx.doi.org/10.5755/j01.ee.28.5.19189
}

Financial cooperation has been popular among different countries since the new century. Recently, the "Silk Road Economic Belt" has attracted the attention of the world. This research focuses on the economic impacts of financial cooperation between different countries along this belt, arguing that the adoption of local currency settlement system is at the initial stage of regional financial cooperation. This research innovatively measures international trade volume, GDP, and welfare among Silk Road and other major countries as a result of financial cooperation through the application of the GTAP model. The results show that, if the local currency settlement system becomes the main model of regional financial cooperation, the appreciation of local currency, e.g. RMB, can increase the GDP in Central Asia, the European countries, and North Africa and optimize the international trade structure in China at the same time. However, the export and import volumes of most industries of the United States, Japan and Australia which do not belong to the Silk Road will suffer from slight declines due to the change of international trade, while their national welfares will increase slightly at the same time. The results have significant implication for relevant researchers, organizations, and government policy makers.

Keywords: Silk Road Economic Belt, Financial Cooperation, GTAP Model, Economic Effect, Measure.

\section{Introduction}

As globalization has become one of the main trends of the world today, the relations between countries are getting closer than ever. Globalization has greatly promoted the economic development of all countries in the world through various cooperation in trade, finance and talent exchange etc. In recent years, with the fast development of China's economy, it has tied itself closely with the rest of the world, and China has become a powerful driving force to stimulate the world economy. However, the world financial crisis in 2008 slowed down the global economic growth, and varying degrees of stagnation of economic development appeared in different regions. For example, China's GDP in 2015, according to the price ratio, only increased by $6.9 \%$ compared to the number in the previous year (Ning, 2016), which was the first time for the growth rate to fall below $7 \%$ during the last 25 years. In addition, the growing limitations of the multilateral framework for global trade have, in part, driven economies to seek new opportunities for development.

Recently, many countries began to sign regional free trade agreements instead of signing the WTO agreement. China should also follow the global trend, exploring new ways of economic cooperation with other countries. In 2013, "Silk Road Economic Belt" was proposed during a speech delivered by the Chinese President Jinping Xi in Kazakhstan Nazarbayev University, focusing on speeding up the economic development in Silk Road countries and improving livelihood in those countries. Silk Road is expected to serve as the world's longest economic belt, which also raises a need of guidelines on financial cooperation among Silk Road countries and the need to develop monetary settlement system. As a result, it is of vital importance to study the international trade volume, GDP, welfare which will affect different countries as a consequence of financial cooperation among Silk Road countries. In fact, so far very little research has touched this new yet very important research area.

Thus, the goal of the research is to critically examine the economic effect of financial cooperation on countries of the "Silk Road Economic Belt" and other main countries such as the United States, Japan and Australia. International trade volume, GDP value, and welfare change are used as proxies to study the economic effect. The main research questions in this study are: 1) What is the economic effect on import and export volumes of Silk Road countries and the United States, Japan and Australia as a result of financial cooperation among Silk Road countries? 2) What is the economic effect on GDP value of Silk Road countries and the United States, Japan and Australia as a result of financial cooperation among Silk Road countries? 3) What is the economic effect on welfare of Silk Road countries and the United States, Japan and Australia as a result of financial cooperation among Silk Road countries?

The paper is then organized in the following way. First the research background, research goal, and research questions are introduced. In the second section a literature review on the topical issue is presented. In the third section the current situation of financial cooperation in Silk Road countries is compared and discussed. Research data and research method are then presented in section four. In the fifth section results are analysed and discussed. The last section is the conclusions. 
Xiaosong Zheng, Lijun Jia. An Empirical Study on the Economic Effect of Financial Cooperation Among Countries of ...

\section{Literature Review}

Financial globalization and financial cooperation have been discussed for a long time by researchers in discussions on economic benefits for a group of countries. Ocampo and Titelman (2009) reviewed the example of sub-regional financial cooperation in South America. The Andean region has succeeded in developing multilateral financial institutions, and financial cooperation has been broader in scope than monetary cooperation. The Andean Development Corporation (CAF) and the Latin American Reserve Fund (FLAR), regarded as the two most successful organizations in the region, are able to provide quality services to their member countries. Furthermore, some researchers pointed out that financial cooperation is more than just to provide services. Cho (2006) states that financial reforms for crisis prevention and financial system soundness have been widely discussed and put in practice worldwide. As in the case of Asia, efforts have been taken to prevent some countries from financial crisis, to stabilize national currency and to establish a platform for market share. In order to prevent the recurrence of financial crisis in East Asia and fully use the resources of financial products, Jang (2008) argues that the Asian bond can be considered as one of the effective methods, proposing institutional buildings including the creation of ACU (Asian Currency Unit) and AMCF (Asian Monetary Cooperation Fund) for improving regional financial cooperation in Asia. In addition, China has taken various positions towards developing proposals for Asian financial regionalism for the last decades, showing enthusiastic participation and contributing substantial contribution (Jiang, 2010).

With the development of economic globalization, the relationship between countries has become increasingly close and complex. Cheng (2014) points out that the international financial crisis and the debt crisis in Europe caused serious impact on China's foreign trade. Seeking opportunities in the competitive global market has become the essential choice to promote China's economic growth. On this regard, China proposed to implement the development strategy on the Silk Road Economic Belt. Liu (2014) claims that the Silk Road Economic Belt is essentially cross-border and sub-regional cooperation form which will promote international trade between countries along the belt. Yao and Huang (2014) further explain that Silk Road countries must deepen financial cooperation and activate financial innovation in order to promote the economic development.

In general, regional financial cooperation can be divided into three levels in a broad sense (Yang, 2011). The first level is the primary stage. At this stage, the characteristic of financial cooperation is bilateral rather than multilateral, and the currency swap agreement is the highest cooperation at this stage. The second level includes exchange rate coordination mechanism. The third level is to unify currency and implement common monetary policy and fiscal policy. Before determining the level of financial cooperation between Silk Road countries, the degree of financial openness in each country should be measured. Therefore, Chinn-Ito index is introduced in this paper. Popova and Rasoulinezhad (2016) use it as an indicator for financial cooperation in a specific country. It sets four dummy variables according to the fact whether a country has restraint in the multiple exchange rates, current account transactions, financial transactions and turning over foreign exchange earnings, and the degree of financial openness can be calculated after standardizing these principal components in each country and region. The degree of financial openness is between -1.84 and 2.84. A greater Chinn-Ito index means that the financial cooperation in this country and region is more open.

However, the financial cooperation status along Silk Road countries remains unknown. Huang (2016) analysed the possibility of Silk Road strategy from the perspective of international investment law. However, the results can be disappointing. The author finds out that there are 61 Bilateral Investment Treaties (BITs) which were signed between China and Silk Road countries and 31 of them may prevent Silk Road strategy from success as a result of ambiguous definitions of 'investor' and 'investment'. There are only limited state dispute resolution mechanisms available in some countries. Huang (2016) regards 'financial viability of cross-border projects' as one of the biggest barriers for the initiative. Ferdinand (2016) further proposed that the practice of this project requires a highlevel participation and strong support from many neighbours, which can lead to risks as big as ambition. To solve these problems, the Asian Infrastructure Investment Bank (AIIB) has been set up and is expected to play an essential role in plugging the infrastructure gaps in Asia, where the investment will reach US $\$ 8$ trillion between the years 2010 and 2020 (Mishra, 2016). However, when studying the financial cooperation between countries along Silk Road, some researchers simply make assumptions on the mode of financial cooperation, while others pay more attention to the process of RMB integration when constructing the Silk Road Economic Belt. There are few researchers who can quantitatively analyse the impact of financial cooperation between countries along the belt, not only on the Silk Road countries but also on the other major countries around the world. This is what this research is going to do, studying and analysing such as an important problem from a comprehensive quantitative perspective.

Fortunately, researchers find a method to study the impact of a particular factor on the global economy. Global Trade Analysis Project (GTAP) model is widely used. The general equilibrium model GTAP is therefore used to simulate the economic consequences of policies in a dynamic framework representing the temporal evolution of macroeconomic and technological parameters (Dandres et al., 2012). It sets the change of the mix of policy and market conditions as a shock to the initial market equilibrium, and then finds out the new balance after the whole world economic system fully adjusts to it. The difference between two balanced situations is regarded as the effect of the shock. Brown (1991) first applied the GTAP model to simulate the economic effects of NAFTA, and the simulation results show that NAFTA can promote regional economic integration in North America effectively. With the growing regional cooperation, researchers began to analyse the economic effect using GTAP model. After that, many researchers applied GTAP model to study regional economy effect due to policy 
changes. Jiang and Li (2012) applied GTAP model to predict the economic and trade effects of the implementation of ECFA from the macroeconomic and industrial level. Peters et al. (2011) tried to reallocate carbon dioxide emissions from producing to consuming countries with GTAP and Multi-Regional Input-Output Analysis (MRIOA) model. Siriwardana and Yang (2008) calculated the change of economic benefits after the successful negotiation on The Australia-China Free Trade Agreement (ACFTA) between the two governments by applying the GTAP model, concentrating on flexible and fixed current account positions within short term and long term, equivalent variation (EV) as well as real consumption. It shows that the agreement can bring positive effects for both China and Australia. Stenberg and Siriwardana (2015) analysed the effects of unilateral trade liberalization of forest products on the Asia-Pacific Economic Cooperation (APEC) member countries and the result is the same as the previous study that countries engaged in international cooperation can gains benefits. Also, Padella et al. (2012) examined the integrated impacts of the US and EU biofuels programs, regarding of socioeconomic effects on prices, employment and welfare in the European Union. Furthermore, GTAP model can be very useful as it can be justified to fulfil the requirements by researchers. Britz and van der Mensbrugghe (2016) used a case showing that the effect of pre-aggregation and filtering on model size, model solution time and simulated welfare impacts with GTAP model as a result that GTAP model provides the capacity to calculate fast and filtering data. Nijkamp et al. (2005) further mentioned GTAP-E model and the authors proposed the question how to cover international emission trading, joint implementation and clean development mechanisms in a computable general equilibrium model such as the GTAP-E model.

However, GTAP model only deals with trade variables, there are almost no researchers applying this model to study the effects of regional financial cooperation. Additionally, this research focuses on a new topic for which it lacks of empirical analysis and calculation. In addition, so far, no researchers have applied GTAP model to quantify the economic impact of financial cooperation between countries along the Silk Road which is one of the most important international strategies China has ever made. Guo (2016) further pointed out that One Belt One Road new strategy is an international strategy which is expected to accelerating industry upgrading and improving the transformation of economic growth mode, contributing to win-win results between China and other related countries. That comes to a critical question, whether and how China and other countries can arrive at the destination of win-win situation? More study and analysis on this important topic is demanded urgently.

Applying the GTAP model creatively, this research attempts to measure the economic effects of the financial cooperation among the Silk Road countries, and it is expected to provide suggestions and implications for relevant researchers, companies, and government decision makers in implementation of the One Belt One Road strategies among the Silk Road countries.

\section{The Current Situation of Financial Cooperation in Silk Road Countries}

In September and October of 2013, during his visit to Central and East Asia countries, Chinese President Jinping $\mathrm{Xi}$ successively proposed the significant suggestions of the Silk Road Economic Belt and 21st Century Maritime Silk Road (Guo, 2016). Silk Road Economic Belt is formed on the basis of the ancient concept of Silk Road, which is considered as one of the most potential economic belts in the world. The initiative is a key element of such a grand strategy and will have far-reaching implications for ChinaEurope relations (Zhao, 2016). According to the different economic characteristics in different economic zones, Silk Road countries can be divided into three sections. The first section is the core area of Silk Road Economic Belt, which includes five Central Asia countries, including Kazakhstan, Kyrgyzstan, Tajikistan, Uzbekistan and Turkmenistan. The second section is the important area of Silk Road Economic Belt, which contains Central Asia, including Russia, Afghanistan, India, Pakistan, Iran, Azerbaijan, Armenia, Georgia, Turkey, Saudi Arabia, Iraq and other regions. The third section is the expansion area of Silk Road Economic Belt named Asia - Europe Economic Belt, including the Europe and North Africa. Germany, France, Britain, Italy, Ukraine and other regions, North Africa, Egypt, Libya, and Algeria are the major countries in this area. In addition, the United States, Japan and Australia are selected as representatives of North America, East Asia and Oceania region respectively, according to their comprehensive national strength and geographical location. The level of financial openness as well as the effects of financial cooperation on Silk Road countries and the United States, Japan and Australia, will be analysed and compared.

Figure 1 compares the degree of national financial openness of Silk Road countries, the United States, Japan and Australia in 1970 to 2014 according to the Chinn-Ito index. From Figure 1, it is easy to find out that the financial cooperation openness in most countries and region has increased steadily, which confirms the trend of closer financial cooperation among these countries. The degree of financial cooperation openness is significantly higher than that of Silk Road countries and regions in the same period. As China, five Central Asia countries and Central Asia are affected by political policy and economic development strategy, Chinn-Ito index is negative for a long time and the degree of financial cooperation openness is relatively low. However, the degree of financial cooperation openness in Asia-Europe economic zone, which includes the Euro area, is relatively higher. It is noteworthy that interregional economic cooperation necessarily requires international financial services with higher quality through financial cooperation among countries. 
Xiaosong Zheng, Lijun Jia. An Empirical Study on the Economic Effect of Financial Cooperation Among Countries of ...

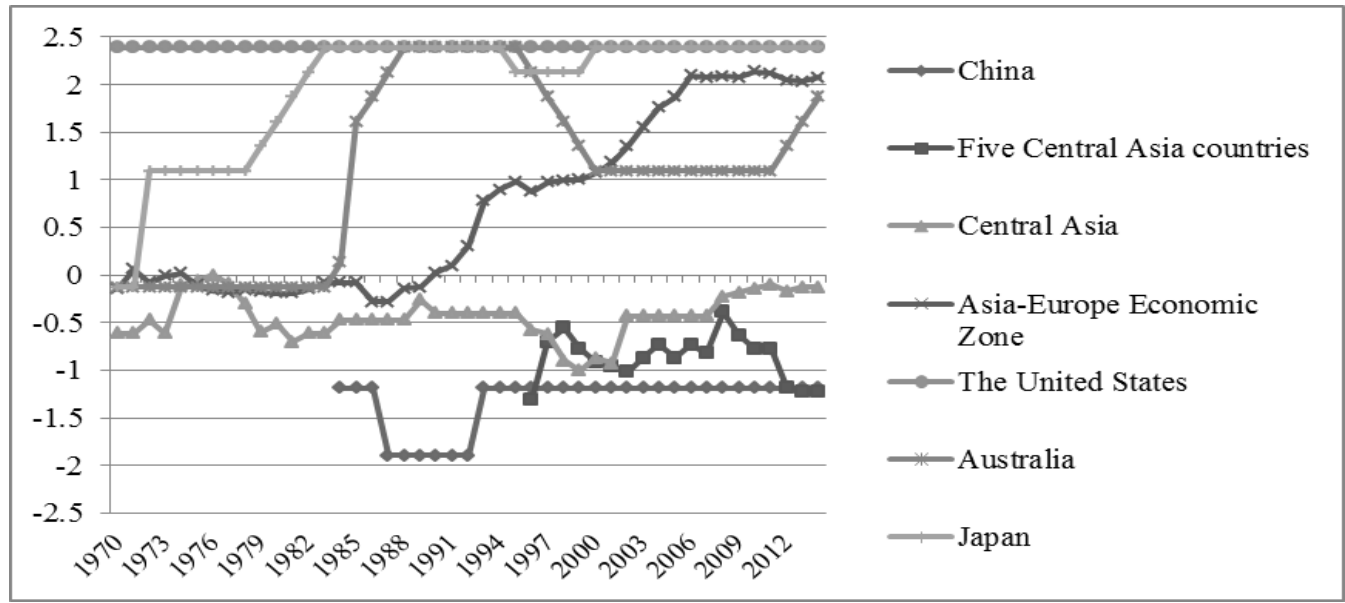

Figure 1. The Comparison of the Degree of Financial Cooperation Openness between Different Countries in the World in 1970-2014

As the sponsor of Silk Road Economic Belt development strategy, China is devoting ongoing efforts to deepen financial cooperation with the Silk Road countries. At present, China has signed currency swap agreements with some major countries along Silk Road Economic Belt, which is the first step for regional financial cooperation. However, the number of countries with agreements and the amount of swap currencies are limited, as shown in Table 1.

Table 1

The Bilateral Currency Swap Agreement between the People's Bank of China and National Central Banks in Silk Road Countries

\begin{tabular}{|c|c|c|c|c|}
\hline Regions & Countries & Signature Date & Amount of Swap Currencies & Valid Period \\
\hline \multirow{3}{*}{$\begin{array}{l}\text { Five Central } \\
\text { Asia Countries }\end{array}$} & Uzbekistan & 2011.4.19 (Expired) & 7 billion RMB / 167 billion Uzbek soums & \multirow{9}{*}{ Three years } \\
\hline & Kazakhstan & $\begin{array}{l}2011.6 .13 \\
2014.12 .14 \text { (Renewed) } \\
\end{array}$ & $\begin{array}{l}70 \text { billion RMB / } 150 \text { billion Kazakhstan tenge } \\
70 \text { billion RMB / } 200 \text { billion Kazakhstan tenge }\end{array}$ & \\
\hline & Tajikistan & 2015.9 .3 & 30 billion RMB / 30 million somoni & \\
\hline \multirow{3}{*}{ Central Asia } & Russia & 2014.10 .13 & 150 billion RMB / 81.5 billion rubles & \\
\hline & Pakistan & $\begin{array}{l}\text { 2011.12.23 } \\
\text { 2014.12.23 (Renewed) }\end{array}$ & $\begin{array}{l}100 \text { billion RMB / } 140 \text { billion Pakistani rupees } \\
100 \text { billion RMB / } 165 \text { billion Pakistani rupees } \\
\text { (Renewed) }\end{array}$ & \\
\hline & Turkey & $\begin{array}{l}2012.2 .21 \\
2015.9 .26 \text { (Renewed) }\end{array}$ & $\begin{array}{l}10 \text { billion RMB / } 30 \text { billion Turkish lira } \\
12 \text { billion RMB / } 50 \text { billion Turkish lira (Renewed) }\end{array}$ & \\
\hline \multirow{3}{*}{$\begin{array}{l}\text { The European } \\
\text { countries }\end{array}$} & United Kingdom & $\begin{array}{l}2013.6 .22 \\
2015.10 .20 \text { (Renewed) } \\
\end{array}$ & $\begin{array}{l}200 \text { billion RMB / } 20 \text { billion pounds } \\
350 \text { billion RMB / } 35 \text { billion pounds (Renewed) }\end{array}$ & \\
\hline & Hungary & 2013.9 .9 & 10 billion RMB / 375 billion Hungarian forint & \\
\hline & European Central Bank & 2013.10 .8 & 350 billion RMB / 45 billion euros & \\
\hline
\end{tabular}

From Table 1, we can see that the amount of swap currencies between China and the European countries as well as Central Asia, especially Russia is relatively high, which is the reflection of close financial cooperation in these countries. From another point of view, the trade relationship between China and these countries is closer so that they have higher requirements of monetary settlement. However, China and some Silk Road countries have no direct monetary cooperation yet, especially with Kyrgyzstan and Turkmenistan which are two core countries in Central Asia.

Except for monetary cooperation, RMB Qualified Foreign Institutional Investors (RQFII) are involved in financial cooperation along Silk Road countries and Table 2 shows the detailed information. According to Table 2, we find that the amount of RQFII set by China is relatively small and the targeted countries only involve the European ones. Therefore, the degree of financial cooperation along Silk Road countries does not meet the expected level, and can only be named an initial stage. As mentioned above, local currency settlement is of the highest priority for the initial stage. To sum up, based on the experience of financial cooperation between China and some Silk Road countries in currency swap, we assume that Silk Road countries will apply local currency settlement system on a wider range and with a higher volume in order to reduce the cost of currency circulation and enhance the ability to resist financial risks.

Table 2

List of RMB Qualified Foreign Institutional Investors (RQFII) in Silk Road Economic Zone (up to March 2016)

\begin{tabular}{|l|l|l|}
\hline Regions & Countries & Currency Amount of RQFII (RMB in billion) \\
\hline \multirow{4}{*}{ The European Countries } & United Kingdom & 80 \\
\cline { 2 - 3 } & France & 80 \\
\cline { 2 - 3 } & German & 80 \\
\cline { 2 - 3 } & Luxembourg & 50 \\
\cline { 2 - 3 } & Hungary & 50 \\
\hline
\end{tabular}


In recent years, currency settlement is widely used in border trade, because the Chinese government has signed border trade settlement agreements with Vietnam, Mongolia, Russia, Nepal, South Korea and other countries. However, due to China's growing economic strength and the reputational guarantee of $\mathrm{RMB}$, it is realistic for $\mathrm{RMB}$ to be the main settlement currency between Silk Road countries.

\section{Research Data and Method}

\section{Data Determination}

This research focuses on financial cooperation between Silk Road countries, and proposes to adopt local currency settlement system as the first step in regional financial cooperation, which is the highest form at that stage. When applying local currency settlement system, the economic effects of the change in exchange rate of settlement currency had on different regions are different. Therefore, it can be regarded as a shock variable to the inherent balance, and the effects on different regions can be calculated through the GTAP model, and these effects includes changes in the value of GDP, trade balance, and economic welfare. Therefore, this research uses the GTAP model to analyse the impact of RMB exchange rate change on the world's major countries at the early stage of financial cooperation.

\section{The Data Source}

All the data in this research mainly come from GTAP 8 database, which contains data of 129 countries and regions, 57 industry sectors (Peters et al., 2011). The data in the GTAP database is derived from national and regional input-output tables and bilateral trade data from the United Nations Trade Statistics. At the same time, international trade data for some countries come from the International Monetary Fund, Food and Agriculture Organization of the United Nations and the World Bank. All the data are integrated by the trading weight of different countries according to the database, and form the GTAP database. In addition, the data of some variable such as COMTRADE in this research come from the People's Bank of China and the People's Republic of China Customs.

\section{Model Simulation}

In order to study the impact of the national financial cooperation on the Silk Road and other countries, we choose research-related countries from the 129 countries in the GTAP database and divide them into four major categories, including China which is the sponsor country, the core area of Silk Road which includes the five Central Asia countries and other Central Asia countries, the expansion area of Silk Road which consists of the European countries and North African countries, and other major countries. Australia is selected as the representative of Oceania region according to its comprehensive national strength and geographical location in Oceania region. Similarly, Japan and the United States are selected as representatives of East Asia and North America respectively. Detailed information is presented in Table 3.

Table 3

\section{Region Division}

\begin{tabular}{|c|l|l|}
\hline \multicolumn{2}{|c|}{ Region } & Country \\
\hline \multicolumn{2}{|c|}{ Sponsor country } & China \\
\hline \multirow{2}{*}{$\begin{array}{c}\text { Central Asia } \\
\text { Europe and North } \\
\text { Africa }\end{array}$} & five Central Asian countries & Kazakhstan, Kyrgyzstan, Uzbekistan, Turkmenistan, Tajikistan \\
\cline { 2 - 3 } & other Central Asian countries & Russia, Turkey, Iran, Saudi Arabia, Pakistan, India \\
\hline \multirow{2}{*}{$\begin{array}{c}\text { Other main } \\
\text { countries }\end{array}$} & the European countries & The European Union and other European countries \\
\cline { 2 - 3 } & North African countries & Egypt, Morocco, Tunisia \\
\cline { 2 - 3 } & Oceania region & Australia \\
\hline
\end{tabular}

In addition, 57 industries in GTAP 8 database are divided into 10 sectors, which are planting, animal husbandry and meat products, digging and mining, food processing, textile and garment, light processing, heavy processing, construction, traffic and communications and services, as shown in Table 4.

Table 4

Industry Division

\begin{tabular}{|l|l|}
\hline \multicolumn{2}{|c|}{ Industry division } \\
\hline Planting & $\begin{array}{l}\text { Wheat, rice, processed rice, cereals, oil crops, } \\
\text { Vegetables and fruits, sugar crops, sugar, plant fiber }\end{array}$ \\
\hline Animal husbandry and meat products & $\begin{array}{l}\text { Cattle and sheep horses, horses and sheep meat products, pigs, pork products, } \\
\text { wool, milk }\end{array}$ \\
\hline Digging and mining & Coal, oil, natural gas, forest, all kinds of metal \\
\hline Food processing & Food, beverages, tobacco \\
\hline Textile and garment & Textiles, clothing, leather \\
\hline Light processing & Wood products, paper products \\
\hline Heavy processing & $\begin{array}{l}\text { Petroleum and coal products, chemical rubber products, mining equipment, } \\
\text { manufacturing products }\end{array}$ \\
\hline Construction & Construction \\
\hline Traffic and communications & Transportation, communications \\
\hline Services & Services and other services \\
\hline
\end{tabular}


Xiaosong Zheng, Lijun Jia. An Empirical Study on the Economic Effect of Financial Cooperation Among Countries of ...

In this research, we assume that RMB appreciate by 5 $\%, 10 \%$, or $15 \%$, which respectively refer to a moderate appreciation of the RMB, a middle level appreciation and a sharp appreciation. Then, we will use the GTAP model to calculate the economic changes in each country and region under each scenario, so as to understand the economic impact of financial cooperation along Silk Road had on major countries and regions.

\section{Results and Analysis}

In this part, we set the appreciation of RMB by $5 \%$, $10 \%$ and $15 \%$ as Scenario (1), (2) and (3) respectively. And the economic effect including trade effect, output effect and welfare effect on Silk Road countries and other major countries are calculated using the GTAP model.

\section{The Trade Effect}

The change of import and export volume in Silk Road regions and other major countries in different scenarios can be obtained through calculations (see Table 5).

Table 5

The Change of Import and Export Volume in Silk Road Regions and Other Major Countries in Different Scenarios (\%)

\begin{tabular}{|c|c|c|c|c|c|c|c|c|c|c|c|c|}
\hline \multirow{2}{*}{$\begin{array}{c}\text { The change of } \\
\text { import volume } \\
(\%)\end{array}$} & \multicolumn{3}{|c|}{ China } & \multicolumn{3}{|c|}{ Central Asia } & \multicolumn{3}{|c|}{ the European countries } & \multicolumn{3}{|c|}{ North African countries } \\
\hline & 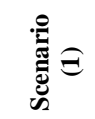 & 苞 & 串 & 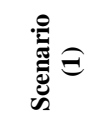 & 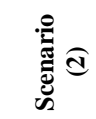 & 串 & 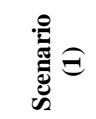 & 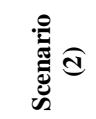 & 莺 & 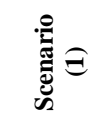 & 莺 & 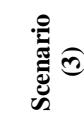 \\
\hline Planting & -0.256 & -0.512 & -0.762 & 0.046 & 0.092 & 0.137 & 0.011 & 0.022 & 0.033 & 0.020 & 0.041 & 0.060 \\
\hline $\begin{array}{l}\text { Animal husbandry } \\
\text { and meat products }\end{array}$ & -0.320 & -0.640 & -0.954 & 0.022 & 0.045 & 0.066 & 0.004 & 0.007 & 0.011 & 0.028 & 0.057 & 0.084 \\
\hline $\begin{array}{l}\text { Digging and } \\
\text { mining }\end{array}$ & -0.058 & -0.116 & -0.175 & 0.002 & 0.003 & 0.005 & 0.001 & 0.001 & 0.002 & 0.010 & 0.021 & 0.031 \\
\hline Food processing & 0.094 & 0.189 & 0.282 & 0.056 & 0.112 & 0.167 & 0.014 & 0.028 & 0.041 & 0.023 & 0.046 & 0.068 \\
\hline $\begin{array}{l}\text { Textile and } \\
\text { garment }\end{array}$ & -0.557 & -1.114 & -1.660 & -0.081 & -0.161 & -0.239 & -0.182 & -0.364 & -0.543 & 0.056 & 0.112 & 0.167 \\
\hline Light processing & -0.165 & -0.331 & -0.494 & -0.009 & -0.020 & -0.029 & -0.009 & -0.019 & -0.028 & -0.003 & -0.005 & -0.008 \\
\hline Heavy processing & -0.110 & -0.220 & -0.330 & -0.023 & -0.046 & -0.069 & -0.008 & -0.015 & -0.023 & -0.005 & -0.009 & -0.014 \\
\hline Construction & 0.141 & 0.283 & 0.423 & 0.104 & 0.208 & 0.311 & 0.057 & 0.113 & 0.170 & 0.091 & 0.183 & 0.274 \\
\hline $\begin{array}{l}\text { Traffic and } \\
\text { communications }\end{array}$ & 0.109 & 0.219 & 0.326 & 0.074 & 0.148 & 0.221 & 0.043 & 0.086 & 0.129 & 0.058 & 0.115 & 0.173 \\
\hline Services & -0.123 & -0.247 & -0.369 & 0.011 & 0.022 & 0.033 & 0.004 & 0.008 & 0.012 & 0.019 & 0.039 & 0.058 \\
\hline \multirow[b]{2}{*}{$\begin{array}{c}\text { The change of } \\
\text { export volume } \\
(\%)\end{array}$} & \multicolumn{3}{|c|}{ China } & \multicolumn{3}{|c|}{ Central Asia } & \multicolumn{3}{|c|}{ the European countries } & \multicolumn{3}{|c|}{ North African countries } \\
\hline & 赵 & 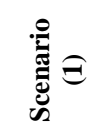 & 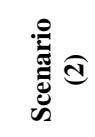 & 串 & 预 & 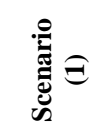 & 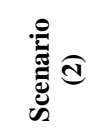 & 营 & 串 & 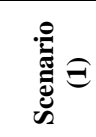 & 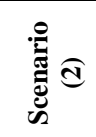 & 离 \\
\hline Planting & 0.480 & 0.962 & 1.440 & -0.038 & -0.077 & 0 & 21 & 12 & 60 & -0.034 & -0.068 & -0.100 \\
\hline $\begin{array}{l}\text { Animal husbandry } \\
\text { and meat products }\end{array}$ & 0.361 & 0.724 & 1.080 & -0.057 & -0.113 & -0.170 & -0.022 & -0.043 & -0.060 & -0.069 & -0.138 & -0.210 \\
\hline $\begin{array}{l}\text { Digging and } \\
\text { mining }\end{array}$ & -0.238 & -0.467 & -0.700 & -0.012 & -0.024 & -0.040 & -0.010 & -0.019 & -0.030 & -0.015 & -0.030 & -0.040 \\
\hline Food processing & 0.811 & 1.623 & 2.430 & -0.050 & -0.101 & -0.150 & -0.040 & -0.080 & -0.120 & -0.053 & -0.106 & -0.030 \\
\hline $\begin{array}{l}\text { Textile and } \\
\text { garment }\end{array}$ & -1.150 & -2.298 & -3.420 & 0.459 & 0.918 & 1.370 & 0.552 & 1.103 & 1.640 & 0.595 & 1.190 & 0.200 \\
\hline Light processing & -0.025 & -0.056 & -0.080 & -0.033 & -0.065 & -0.100 & -0.012 & -0.024 & -0.040 & -0.025 & -0.049 & 0.040 \\
\hline Heavy processing & -0.069 & -0.137 & -0.210 & -0.021 & -0.043 & -0.060 & -0.005 & -0.011 & -0.020 & 0.009 & 0.018 & 0.030 \\
\hline Construction & 2.315 & 4.632 & 6.940 & -0.081 & -0.161 & -0.240 & -0.075 & -0.150 & -0.220 & -0.090 & -0.179 & -0.080 \\
\hline $\begin{array}{l}\text { Traffic and } \\
\text { communications }\end{array}$ & 0.739 & 1.479 & 2.220 & -0.053 & -0.107 & -0.160 & -0.046 & -0.092 & -0.140 & -0.065 & -0.130 & -0.060 \\
\hline Services & 0.169 & 0.339 & 0.510 & -0.030 & -0.059 & -0.090 & -0.016 & -0.032 & -0.050 & -0.039 & -0.079 & 0.030 \\
\hline
\end{tabular}

According to Table 5, when applying local currency settlement system, the appreciation of RMB causes the declines in import volume in most industries in China, but food processing industry, construction industry and transportation as well as communication industry show a slight upward trend. Among these sectors, the construction sector shows the most significant increase in Scenario (1).
It increases by $0.141 \%$ while the animal husbandry meat products industry and textile and garment industry show the most obvious decline in Scenario (1), and they all decrease more when the appreciation of RMB is higher.

Similarly, the appreciation of RMB can increase import volume in most industries in Silk Road regions. In Central Asia, the construction, transportation and 
communications as well as food processing industry show the most obvious increase in Scenario (1) and more in Scenario (3). The same changes are in Europe and other regions. However, according to our research, we find that the import volume in most industries in the United States, Japan and Australia shows slight declines, while the import volume in textile and garment industry, processing industry and heavy processing industry rises slightly. This means people in the United States, Japan and Australia show less willingness to buy Chinese textile and apparel products which are exported less and relatively more expensive than products from other Silk Road Countries for which people in the United States, Japan and Australia show more interests.

From the Table 5, we can also get results about changes in exports. The export volume in China's mining industry, textile and garment industry, light industry and heavy processing industry declines to some extent. Particularly, the decreasing effect on textile and garment industry is the most obvious, and it declines by $1.150 \%$, $2.298 \%$ and $3.420 \%$ respectively in Scenario (1), (2) and (3), while the export volume in textile and garment industry in Central Asian countries and the EU countries increases to some extent. Besides textile and garment industry, the export volume of heavy processing industry in North African countries also rises slightly. However, the export volume in most industries in the United States, Japan and Australia shows different degrees of decline due to the transfer of trade.

\section{The Output Effect}

GDP is an output indicator for macroeconomics (Wan, 2011). The change of GDP value in the main regions along Silk Road and other main countries in different scenarios can be calculated by the GTAP model and the results are listed in Table 6.

Table 6

GDP Change in Different Countries and Regions (\%)

\begin{tabular}{|c|c|c|c|c|c|c|c|}
\hline GDP change (\%) & China & Central Asia & $\begin{array}{c}\text { the European } \\
\text { countries }\end{array}$ & $\begin{array}{c}\text { North African } \\
\text { countries }\end{array}$ & $\begin{array}{c}\text { The United } \\
\text { States }\end{array}$ & Japan & Australia \\
\hline Scenario (1) & -0.056 & 0.011 & 0.011 & 0.012 & 0.002 & -0.003 & 0 \\
\hline Scenario (2) & -0.112 & 0.022 & 0.021 & 0.025 & 0.003 & -0.006 & -0.001 \\
\hline Scenario (3) & -0.168 & 0.033 & 0.032 & 0.037 & 0.005 & -0.009 & -0.001 \\
\hline
\end{tabular}

According to Table 6 , the influence of financial cooperation on different Silk Road countries is different. First, the higher the appreciation of RMB becomes, the more GDP value in China decreases. However, the appreciation of RMB has positive effects on Central Asia, Europe and North Africa. Furthermore, the GDP value in these regions becomes larger with higher appreciation of
RMB. The level of influence RMB appreciation had on other main countries becomes much smaller.

There is more information which needs to be further discovered. Thus, this research deconstructs national output according to 10 industries to find out the industry structural effects of financial cooperation. The results are presented in Table 7 .

Table 7

Output Change in Different Countries and Regions (\%)

\begin{tabular}{|c|c|c|c|c|c|c|c|c|c|c|c|c|}
\hline \multirow[b]{2}{*}{$\begin{array}{c}\text { Output } \\
\text { change in Silk } \\
\text { Road } \\
\text { countries }(\%)\end{array}$} & \multicolumn{3}{|c|}{ China } & \multicolumn{3}{|c|}{ Central Asia } & \multicolumn{3}{|c|}{ the European countries } & \multicolumn{3}{|c|}{ North African countries } \\
\hline & 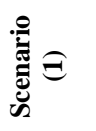 & 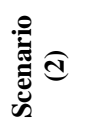 & 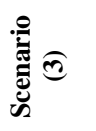 & 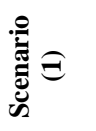 & 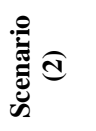 & 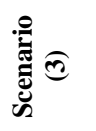 & 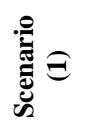 & 芴 & 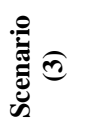 & 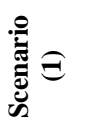 & (ָ) & 串 \\
\hline Planting & -0.002 & -0.003 & -0.004 & -0.001 & -0.002 & -0.003 & -0.005 & -0.010 & -0.015 & -0.011 & -0.021 & -0.031 \\
\hline $\begin{array}{l}\text { Animal } \\
\text { husbandry and } \\
\text { meat products }\end{array}$ & -0.001 & -0.001 & -0.002 & -0.003 & -0.006 & -0.008 & -0.009 & -0.018 & -0.027 & 0.002 & 0.004 & 0.007 \\
\hline $\begin{array}{l}\text { Digging and } \\
\text { mining }\end{array}$ & 0.033 & 0.066 & 0.098 & -0.005 & -0.011 & -0.016 & -0.006 & -0.012 & -0.017 & -0.007 & -0.014 & -0.021 \\
\hline $\begin{array}{l}\text { Food } \\
\text { processing }\end{array}$ & 0.067 & 0.135 & 0.202 & -0.012 & -0.024 & -0.036 & -0.014 & -0.029 & -0.043 & -0.019 & -0.039 & -0.058 \\
\hline $\begin{array}{l}\text { Textile and } \\
\text { garment }\end{array}$ & -0.568 & -1.135 & -1.689 & 0.246 & 0.492 & 0.732 & 0.396 & 0.791 & 1.178 & 0.257 & 0.513 & 0.765 \\
\hline $\begin{array}{l}\text { Light } \\
\text { processing }\end{array}$ & 0.000 & -0.001 & -0.002 & -0.002 & -0.004 & -0.006 & -0.003 & -0.006 & -0.008 & 0.003 & 0.007 & 0.011 \\
\hline $\begin{array}{l}\text { Heavy } \\
\text { processing }\end{array}$ & 0.008 & 0.016 & 0.022 & 0.006 & 0.013 & 0.019 & 0.001 & 0.001 & 0.002 & 0.013 & 0.025 & 0.038 \\
\hline Construction & 0.003 & 0.005 & 0.008 & -0.004 & -0.008 & -0.011 & -0.006 & -0.012 & -0.018 & 0.000 & 0.001 & 0.001 \\
\hline $\begin{array}{l}\text { Traffic and } \\
\text { communicatio } \\
\text { ns }\end{array}$ & 0.067 & 0.135 & 0.202 & -0.004 & -0.009 & -0.013 & -0.011 & -0.022 & -0.033 & -0.015 & -0.029 & -0.043 \\
\hline Services & 0.005 & 0.010 & 0.014 & -0.003 & -0.006 & -0.010 & -0.002 & -0.004 & -0.006 & -0.006 & -0.012 & -0.017 \\
\hline
\end{tabular}


According to Table 7, financial cooperation can bring benefits to Silk Road countries. First, the output of most industries in Chinese rises and the output structure is optimized gradually when RMB appreciates. Furthermore, the output of textile and garment industry and heavy processing industry in Central Asia and the Europe rises considerably when RMB appreciates. The increase in the output of textile and garment industry is obvious and it goes up by $0.246 \%$ and $0.396 \%$ respectively in Central Asia and the Europe in scenario (1). North Africa faces the similar circumstance. The output of textile and garment industry in North Africa grow s by $0.0257 \%$ and the output of light processing industry and heavy processing industry in this region goes up slightly by $0.003 \%$ and $0.013 \%$ in scenario (1).

According to our research, financial cooperation along Silk Road countries may cause output loss in most industries in the United States, Japan and Australia to some extent. The output in most industries including planting industry, animal husbandry and meat products industry, food processing industry, textile and garment industry, light processing industry, heavy processing industry and traffic and communications industry in the United States declines when RMB appreciates.

\section{The Welfare Effect}

Besides studying the trade effect and output effect, it is necessary to measure the welfare effects of financial cooperation. In this section, GTAP model is still applied to measure and compare the change of welfare caused by financial cooperation in Silk Road countries and other major countries. Formula 1 is used for calculation, which involves the idea of equivalent variation (Wan, 2011).

$$
\mathrm{EV}(\mathrm{p} 0, \mathrm{p} 1, \mathrm{w})=\mathrm{e}(\mathrm{p} 0, \mathrm{u} 1)-\mathrm{e}(\mathrm{p} 0, \mathrm{u} 0)=\mathrm{e}(\mathrm{p} 0, \mathrm{u} 1)-\mathrm{w}(1)
$$

Formula 1 is interpreted as the income required making consumers reach the utility level before the price changes when the price changes. Based on this formula, the welfare effects on different regions and countries can be calculated, and detailed information is shown in Table 8.

Table 8

The Change of Welfare in Silk Road Countries and Other Major Countries in Different Scenarios (\%)

\begin{tabular}{|c|c|c|c|}
\hline \multicolumn{4}{|c|}{ Equivalent Variation (billion dollars) } \\
\hline & Scenario (1) & Scenario (2) & Scenario (3) \\
\hline China & -268.15 & -337.63 & -799.63 \\
\hline Central Asia & 85.58 & 237.26 & 257.73 \\
\hline the European countries & 428.91 & 1107.92 & 1279.66 \\
\hline North African countries & -14.24 & -40.10 & -43.13 \\
\hline The United States & 88.17 & 226.46 & 264.84 \\
\hline Japan & 4.20 & 16.3 & 12.73 \\
\hline Australia & 3.29 & 10.99 & 9.94 \\
\hline
\end{tabular}

According to Table 8, China's welfare effects will be negatively affected by the financial cooperation when RMB appreciates. If RMB appreciates by $15 \%$, the China's consumer welfare will be reduced by 800 million USD. It fully highlights that the exchange rate adjustment is a double-edged sword. The appreciation of RMB can increase the price of our products in the world market. On the other hand, the export products in China are labour intensive instead of technology-intensive so that they are vulnerable to price. Therefore, the appreciation of RMB can decrease the competitiveness of our products in the world market, reducing China's export volume and employment rate, which results in economic slowdown or even a bottleneck. At the same time, the appreciation of the RMB will directly weaken the attractiveness of the market in China to foreign investment. Foreign investors are likely to reduce investment in advanced technology and equipment, which is not conducive to the industrial restructuring in China, reducing China's welfare. From table 8 , we can also find that financial cooperation along Silk Road brings benefits to the welfare in Central Asia and the Europe when RMB appreciates. In addition, the welfare in the United States, Japan and Australia increases to some extent in different scenarios. The welfare growth in the United States is the most obvious and it increases by 264 million US dollars in Scenario (3). However, the growth range in Europe is higher than that in the United States. To sum up, financial cooperation along Silk Road countries can significantly improve the welfare in Silk
Road countries while the welfare in other major countries increases slightly.

\section{Conclusions}

As the increasing trend of economic globalization, the relationship between the various economies becomes increasingly complex, and competition is inevitable. Silk Road Economic Belt proposed by China brings golden opportunities for countries along the Silk Road. This study innovatively applied the GTAP model to measure the economic effects of financial cooperation among Silk Road countries and other main countries. Recall the three research questions in this study: 1) What is the economic effect on import and export volumes of Silk Road countries and the United States, Japan and Australia as a result of financial cooperation among Silk Road countries? 2) What is the economic effect on GDP value of Silk Road countries and the United States, Japan and Australia as a result of financial cooperation among Silk Road countries? 3) What is the economic effect on welfare of Silk Road countries and the United States, Japan and Australia as a result of financial cooperation among Silk Road countries? The conclusions are then presented in the order of answering the three research questions.

First, only the import volume of food processing industry, construction industry and transportation show slight increase in China, while the import volume in other industries show general decline. This might because its 
national economy has showed a characteristic of "new normal" over the recent years. The economy has shifted gear from the previous high speed to a medium-to-high speed growth and the demand for imported raw materials and semi-finished products declines. However, in the same scenarios, it can increase the import volume in most industries in other Silk Road regions. In addition, the import volume in most industries in the United States, Japan and Australia shows slight declines, while the import volume in textile and garment industry, processing industry and heavy processing industry in these countries rises slightly.

For the export volume, the mining industry, textile and garment industry, light industry and heavy processing industry in China declines to some extent. Particularly, the decreasing effect on textile and garment industry is the most obvious. In addition, the export volume in textile and garment industry in Central Asian countries and the EU countries increases to some extent, while that in other industries declines. It is reasonable to get the idea that China and other Silk Road countries have a certain trade complementarity in textile and garment industry and the construction industry. However, the United States, Japan and Australia which do not belong to Silk Road countries are likely to be negatively affected by the transfer of trade. In addition, the import and export volumes in most industries in these three countries showed different degrees of decline.

Secondly, although the influence of financial cooperation on different Silk Road countries is different, it is recognized that financial cooperation can bring output benefits to Silk Road countries. If the system of local currency settlement is adopted, the GDP value in China will decrease, but the output structure can be optimized as the output of technology-intensive industries increases. Furthermore, the GDP value in Central Asia, Europe and North Africa becomes larger. The output of textile and garment industry and heavy processing industry in Central Asia and Europe rises considerably when RMB appreciates. In addition, financial cooperation along Silk Road countries may lead to output loss in most industries in the United States, Japan and Australia, the output of most industries in the United States, Japan and Australia declines when RMB appreciates.

Thirdly, the change of welfare in different countries might be different. First, China's welfare will be negatively affected by the financial cooperation; however, financial cooperation along Silk Road brings benefits to the welfare in Central Asia and the Europe as well as other three major countries. In conclusion, financial cooperation along the Silk Road can bring certain benefits to Silk Road countries, and the interests in other countries worldwide may also increase.

\section{Acknowledgement}

This research is funded by the General Project of National Planning Office of Philosophy and Social Science (2015, Project No. 15BJL080) and the Major Project of National Planning Office of Philosophy and Social Science (2014, Project No. 14AGJ006).

\section{References}

Britz, W., \& van der Mensbrugghe D. (2016). Reducing Unwanted Consequences of Aggregation in Large-Scale Economic Models - A Systematic Empirical Evaluation with the GTAP Model, Economic Modelling, 59, 463-472. https://doi.org/10.1016/j.econmod.2016.07.021

Brown, P. (1991). A Canada-US Customs Union: An Economic Evaluation, North American Journal of Economics and Finance, 37-76.

Chen, J. (2014). New Opportunities and Challenges Silk Road Economic Belt Construction Bringing to China's Foreign Trade, Economic and Trade, (6), 92-96.

Cho, B. (2006). Financial Globalization and Financial Cooperation in East Asia, Journal of Korean Economic Development, 1(12), 117-145.

Dandres, T., Gaudreault, C., Tirado-Seco, P., \& Samson, R. (2012). Macroanalysis of the Economic and Environmental Impacts of a 2005-2025 European Union Bioenergy Policy Using the GTAP Model and Life Cycle Assessment, Renewable \& Sustainable Energy Reviews, 2(16), 1180-1192. https://doi.org/10.1016/j.rser.2011.11.003

Ferdinand, P. (2016). Westward Ho-The China Dream and 'one Belt, One Road': Chinese Foreign Policy under Xi Jinping, international Affairs, 4(92), 941.

Guo, X. J. (2016). A Study on the International Tourism of Jiangxi Province under the Guidance of One Belt, One Road Strategy, Economic and Social Changes-Facts Trends Forecast, 3(45), 221-230. https://doi.org/10.15838/ esc.2016.3.45.13

Huang, J. (2016). Silk Road Economic Belt: Can Old BITs Fulfil China's New Initiative, Journal of World Trade, 4(50), 733-754.

Huang, L., \& Huang, X. (2012). The Effects of Financial Cooperation on BRICS and International Economies, Economist, 4, 77-85.

Huang, Y. P. (2016). Understanding China's Belt \& Road Initiative: Motivation, Framework and Assessment, China Economic Review, 40, 314-321. https://doi.org/10.1016/j.chieco.2016.07.007

Jang, W. H. (2008). Regional Financial Cooperation in Asia: Institutional Approach, Journal of Economics Studies, 4(26), 265-295. 
Xiaosong Zheng, Lijun Jia. An Empirical Study on the Economic Effect of Financial Cooperation Among Countries of ...

Jiang, Y. (2010). Response and Responsibility: China in East Asian Financial Cooperation, Pacific Review, 5(23), 603623.

Liu, S. (2014). Along the Way: A New Approach to the Study of Cross - border Sub Regional Cooperation Theory, Study on South Asian, (2), 2-11.

Mishra, R. (2016). Asian Infrastructure Investment Bank: An Assessment, India Quarterly-A Journal of International Affairs, 2(72), 163-176.

Nijkamp, P., Wang, S. L., \& Kremers H. (2005). Modeling the Impacts of International Climate Change Policies in a CGE Context: The Use of the GTAP-E model, Economic Modelling, 6(22), 955-974. https://doi.org/10.1016/j. econmod.2005.06.001

Ning, J. (2016). China Statistical Yearbook 2016. China Statistics Press.

Ocampo, J. A., \& Titelman, D. (2009). Subregional Financial Cooperation: The South American Experience, Journal of Post Keynesian Economics, 2(32), 249-268. https://doi.org/10.2753/PKE0160-3477320208

Padella, M., Finco, A., \& Tyner, W. E. (2012). Impacts of Biofuels Policies in the EU, Economics of Energy \& Environmental Policy, 3(1), 87-103. https://doi.org/10.5547/2160-5890.1.3.6

Peters, G., Andrew, R., \& Lennox, J. (2011). Constructing an Environmentally Extended Multi-Regional Input -Output Table Using the GTAP Database, Economic Systems Research, 23(6),131-152. https://doi.org/10.1080/095353 14.2011.563234

Petri, P. A., Plummer, M. G., \& Zhai, F. (2012). The Trans-Pacific Partnership and Asia- Pacific Integration: A Quantitative Assessment, General Information, 4(2), 381-383.

Pillarisetti, J. R., Lawrey, R., \& Rade, K. (2007). GM cropsinsub-Saharan Africa: Acritical Comment on GTAP Modeling, International Journal of Social Economics, 343-352.

Popova, L., \& Rasoulinezhad, E. (2016). Have Sanctions Modified Iran's Trade Policy? An Evidence of Asianization and De-Europeanization through the Gravity Model, Economies, 4(4).

Shahid, A. (2011). Economic and Welfare Impacts of Prospective India-Australia FTA Using GTAP and SMART Models, Business and Emerging Markets, 3(4), 396-416. https://doi.org/10.1504/IJBEM.2011.042999

Shen X., \& Xiao J. The New Situation of International Regional Economic Cooperation and China's Strategy of Silk Road Belt', Macroeconomic Research, (11), 31-38.

Sheng, L. (2015). Impact of the Trans-Pacific Partnership on China's Textiles and Apparel Exports: A Quantitative Analysis, The International Trade Journal, 1(29), 19-38.

Siriwardana, M., \& Yang, J. M. (2008). GTAP Model Analysis of the Economic Effects of an Australia-China FTA: Welfare and Sectoral Aspects, Global Economic Review, 3(37), 341-362. https://doi.org/10.1080/12265 080802273315

Stenberg, LC., \& Siriwardana, M. (2015). Measuring the Economic Impacts of Trade Liberalization on Forest Products Trade in the Asia-Pacific Region Using the GTAP Model, International Forestry Review, 4(17), 498-509. https://doi.org/10.1505/146554815817476459

Wan, L. (2011). The Economic Implications of the New American Trans-Pacific Economic Partnership (TPP) Strategy: An Analysis Based on the GTAP Model, Journal of Contemporary Asia-Pacific Studies (Bimonthly), 4, 60-73.

Wang, X., \& Yu B. (2015). A Study on the Gradual Path of the Internationalization of the RMB Area in the Silk Road Economic Belt, Economist, (6), 68-77.

Yang, J. (2011). The Theory and Practice of International Financial Cooperation, Special Zone Economy, (6), 92-93.

Yao, D., \& Huang X. (2014). China's Financial Cooperation with Silk Road Economic Belt Countries: Status Quo, Challenges and Prospects, International Trade, (10), 37-41.

Zhao, M. H. (2016). The Belt and Road Initiative and its Implications for China-Europe Relations, International Spectator, 4(51), 109-118.

Zheng, L. (2006). Regionalization of RMB and the Expansion of Local Currency Settlement in Border Trade, International Trade, (7), 43-45.

The article has been reviewed.

Received in October, 2017; accepted in December, 2017. 